\title{
Accounting
}

\section{Manager's ability, wage minimum policy, and firm size on firm performance: An empirical analysis in the real estate and construction sector}

\section{Nguyen Ho Phi Ha ${ }^{a^{*}}$ and Nguyen Quang Minh ${ }^{b}$}

${ }^{a}$ Academy of Finance, Bac Tu Liem district, Hanoi, Vietnam

${ }^{b}$ University of Finance - Marketing, Ho Chi Minh City, Vietnam

\section{CH R O N I C L E}

\section{Article history:}

Received: December 10, 2020

Received in revised format:

January 32021

Accepted: January 8, 2021

Available online:

January 8, 2021

Keywords:

Minimum Wage Policy

Firm Size

Firm Performance

Real Estate

Construction Sector

\section{A B S T R A C T}

The real estate and construction industry have significantly played a particularly important role in economic development in each economy. In the case of Vietnam, the real estate and construction industry have greatly contributed a large proportion to the gross domestic product (GDP) growth with a sustainable annual growth. The purpose of this study is to examine the impact of manager's ability, wage minimum policy, and firm size on firm performance. Using 220 real estate and construction firms in the case of Vietnam, results depict that a greater ability of managers in the real estate and construction sector will significantly enhance the efficiency of businesses. In addition, a larger firm can reach a higher firm efficiency while the efficiency of the real estate and construction firms is not impacted by changes of wage minimum policy.

\section{Introduction}

All countries aim to find and increase the financial resources they can obtain in order to achieve economic growth and social improvement. In which, supporting businesses in their countries can increase income, quality of life, and the purpose of poverty reduction, therefore, businesses have played a major role in most economies from developed and emerging economies in general and developing economies in particular. In most countries, small and medium-sized enterprises (SMEs) contribute more than a half of GDP, and therefore, support for SMEs is one of the most priorities for economic growth, job creation (Nguyen and Pham, 2017; Nguyen et al., 2020). Over the past few decades, there has been increasing recognition of the importance of SMEs in recent years, firstly, SMEs are independent firms, registered for business in accordance with the corporate laws, with a low of registered capital or the average annual number of employees does not exceed a threshold level based on the specific country. In addition, SMEs are less likely to be able to receive bank loans than larger firms, in fact, they are likely to be reliant on internal funds, especially cash from friends, relatives or family in order to start business (Huynh, 2020; Nguyen and Pham, 2017; Sadiq et al., 2019; Nguyen et al., 2020).

In the case of Vietnam, most of the real estate and construction industry are medium and small- sized. Nowadays, SMEs have significantly played a very important role in robustness of economic growth, and accounted for over 95 percent of all firms in the country. Up to 2019, Vietnam has approximately 700 thousand firms with nearly 600 thousand private enterprises which contribute 40 percent of GDP and roughly 50 of job creation. To keep sustainable development in the long term, Vietnam is currently

* Corresponding author.

E-mail address: nguyenhophiha3@gmail.com (N.H.P. Ha) 
encouraging more foreign investments as well as conducting startup programs in order to enhance growth and strongly focus on providing incentives to SMEs (Nguyen and Pham, 2017; Le et al., 2020; Sadiq et al., 2020). In which, Hanoi is a major and capital city of the country, and the total number of enterprises in Hanoi city are approximately 286,631 enterprises, in terms of the number of enterprises, districts of Ha Dong, Cau Giay, Dong Da, Hoang Mai, Nam Tu Liem, and Thanh Xuan have the number of registered enterprises with the most of new establishments.

In the case of Cau Giay district, Hanoi, up to 2019, there were about 870 real estate and construction firms in this district. Specifically, SMEs in general, and real estate and construction firms in particular have significantly played an important role in ensuring local socio-economic stability in the district, the activities of production and business of SMEs have increasingly developed in both quantity and quality. In 2019, the whole district had 134 new real estate and construction enterprises with a total capital of over 1200 billion VND, but the number of giant real estate and construction firms are relatively modest and much lower than few emerging districts in the capital city. Additionally, most businesses still faced many difficulties in building brands, products, management skills, small scale, low capacity of accessing capital, lack of linkages between businesses in the area.

For that purpose, this study result will contribute the theoretical framework of manager's ability, wage minimum policy, and firm size on firm performance. In addition, the research results can also discuss the findings for the real estate and construction sector in order to show how to enhance their performance. The remaining content of this study will discuss as: Section 2 depicts literature review. Section 3 depicts both data collection and research methods while research results for Section 4 . In addition, Section 5 indicates the conclusions.

\section{Literature review}

The relationship between manager's ability, wage minimum policy, firm size and firm performance has been conducted by numerous previous empirical studies worldwide. Vanacker et al. (2020) studied research about two factors as home country intellectual property, and staff protection and its impact on firm performance by using 9642 European firms. Further investigated on this, Vanacker et al. (2020) found that internal corporate entrepreneurship has a positive and significant impact on firm performance in economies with less intellectual property production and less staff protection. In addition, external corporate entrepreneurship has a negative and significant impact on firm performance in economies with less intellectual property production and more staff protection.

In a study of $\mathrm{Ni}$ and Kurita (2020) with the research about how the interrelationship between minimum wage, export behavior, and firm performance in Indonesia covered in the period of $2002-2014$. Using a two stage least squares regression, and firmlevel data in the manufacturing sector, $\mathrm{Ni}$ and Kurita (2020) conclude that a higher level of minimum wage is consistent with a lower level of employment and productivity of firms, but enhanced in ability of exporting. Further discussed by using the 2012 wage policy reform through applying a difference-in-difference analysis and more discussion about the potential endogeneity of minimum wage regulation, $\mathrm{Ni}$ and Kurita (2020) found that three factors such as average wage, firm size, and education level of workers have significantly impacted firm performance. Additionally, export performance in Indonesia, and comparative advantage in the global market are not much affected by a higher labor cost that is supported by minimum wage growth. Discussed on innovation and firm performance, Burrus et al. (2018) indicate that innovation can enhance firm performance, investment, and growth for the firm and community. In the case of US, Burrus et al. (2018) further suggest that inventive activity in the country is positively correlated with sales and profit growth meanwhile technical creativity is also correlated with process enhancement, and net income growth.

Similarly, the aim of demonstrating the importance of innovation to firm performance, research by Giannetti (2019) in European manufacturing firms. Giannetti (2019) in a study in European manufacturing sector to conduct the relationship between debt specialization and firm turnover reduction in the period of economic crisis. Using the methodology of the generalized propensity score matching and followed by Hirano and Imbens (2004), Imai and Van Dyk (2004), Giannetti (2019) suggests that firm turnover reduction at each debt concentration level on average, and similar to the theory of De Fiore and Uhlig (2015). Further, a firm with a greater diversification of debt structure will be less likely to experience a high turnover reduction. The similar research is also conducted in Kalkan et al. (2011). According to Kalkan et al. (2011) in a study the impact of firm size, system of information, and other factors on efficiency of firms in Isparta, in Turkey. More specifically, Croteau and Bergeron (2011) indicate that technological architecture was estimated for the profiles of technological deployment while firm size is measured by the number of employees. 


\section{Data and Research Methods}

\subsection{Data}

First, we need to estimate the optimal sample size in this study. We choose the necessary sample size to satisfy both factor analysis EFA and multivariate regression is $\mathrm{N}=\max (5 \times \mathrm{x}$; 5+8p) (Mukherjee et al., 2017; Sinha and Mukherjee, 2020). In most cases, the samples may lack information, we will select 240 surveys and control the samples obtained throughout the survey process. After collecting data, questionnaires are examined and unsatisfactory questionnaires are removed. The optimal sample size is 220. Data is collected from the primary data in the Cau Giay district, Hanoi, Vietnam.

\subsection{Research Methods}

On the basis of inheriting the research model of Vanacker et al. (2020), Ni and Kurita (2020), Giannetti (2019), Burrus et al. (2018) and other previous studies regarding firm performance, in this study, we propose the research model according to the multiple regression model. In this study, we will discuss the relationship between independent variables and one dependent variable. The model is of the form:

$$
Y_{i}=\beta_{0}+\beta_{1} X_{1 i}+\beta_{2} X_{2 i}+\ldots+\beta_{h} X_{h i}+\ldots+\beta_{n} X_{n i}+\varepsilon_{i}
$$

where:

$X_{h i}$ : the value of the $\mathrm{h}$ independent variable at the $\mathrm{i}$ observation.

$\beta_{h}:$ the partial regression coefficient.

$\varepsilon_{i}$ : independent random variable with normal distribution with mean of 0 and constant variance $\sigma^{2}$ (error).

\section{Table 1}

Summary of variables in the research model

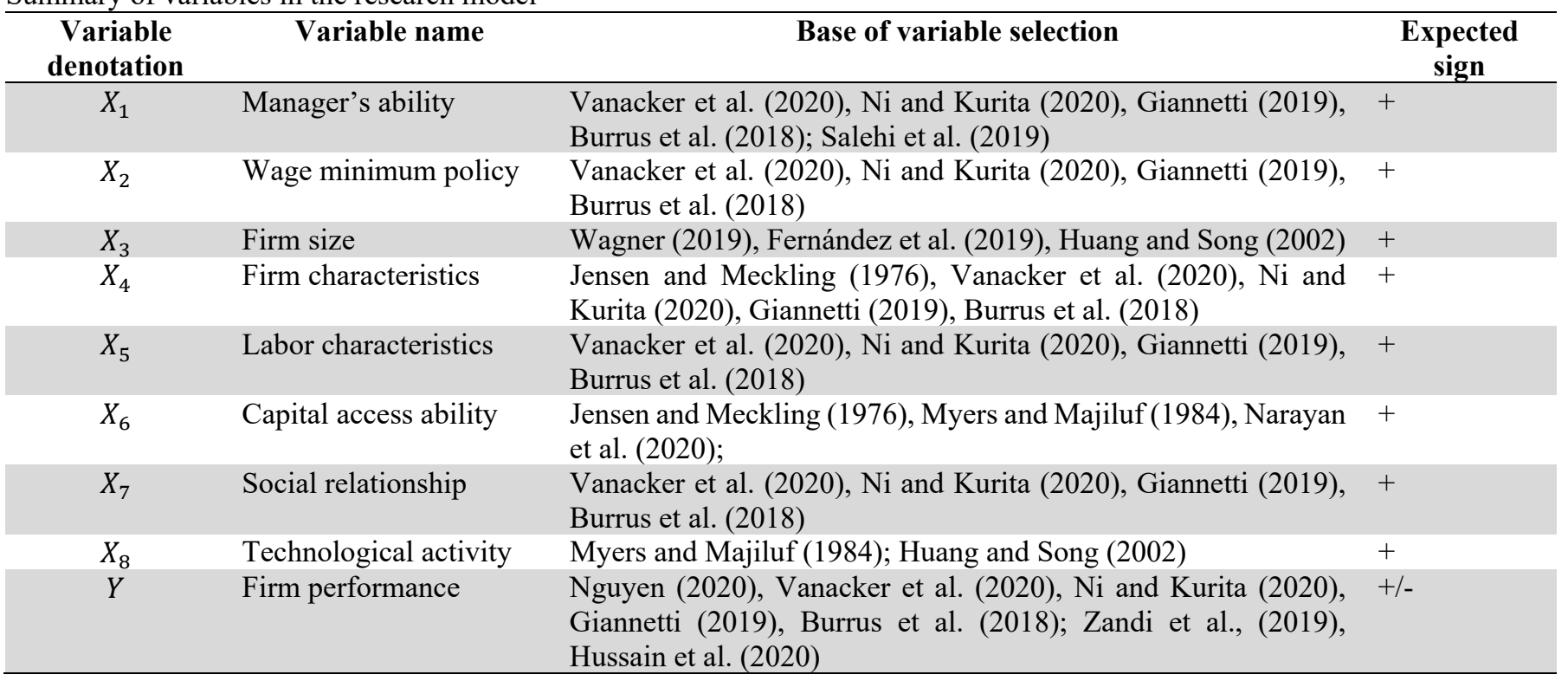

Source: Synthesis

Followed by Narayan et al. (2020), capital structure based on the trade-off, pecking order, and the market timing theories by using a sample of stocks and the leverage speed of adjustment. In addition, Myers and Majiluf (1984); Narayan et al. (2020) found that the leverage speed of adjustment will be faster in Islamic stocks compared to that on conventional stocks, and it is consistent with trade-off theory. In addition, the costs of external funding are very high (Myers, 1984). Additionally, Jensen and Meckling (1976); Jensen (1986) indicate the agency cost theory holds that capital structure will be an effective governance tool to solve the agency cost problem. 


\section{Research results}

Table 2 below indicates the regression results regarding firm performance, in which, we will discuss more variables that impact on firm performance. The study will show the following results:

Table 2

Results of regression model

\begin{tabular}{|c|c|c|c|c|c|c|c|}
\hline \multirow[t]{2}{*}{ Variable } & \multicolumn{2}{|c|}{$\begin{array}{c}\text { Unstandardized regression } \\
\text { coefficient }\end{array}$} & \multirow{2}{*}{$\begin{array}{c}\text { Standardized } \\
\text { regression } \\
\text { coefficients }\end{array}$} & \multirow[t]{2}{*}{$\mathrm{t}$} & \multirow[t]{2}{*}{ Sig. } & \multicolumn{2}{|c|}{ Multi-collinear statistics } \\
\hline & Beta & Standard error & & & & Acceptability & VIF \\
\hline Constant & -0.003 & 0.023 & & -0.057 & 0.987 & & \\
\hline Manager's ability & 0.113 & 0.034 & 0.134 & 3.467 & 0.000 & 0.593 & 1.686 \\
\hline Wage minimum policy & 0.345 & 0.066 & 0.223 & 0.565 & 0.232 & 0.603 & 1.656 \\
\hline Firm size & 0.234 & 0.022 & 0.256 & 3.243 & 0.000 & 0.697 & 1.434 \\
\hline Firm characteristics & 0.212 & 0.033 & 0.256 & 6.234 & 0.000 & 0.608 & 1.645 \\
\hline Labor characteristics & 0.012 & 0.054 & 0.077 & 0.678 & 0.345 & 0.638 & 1.565 \\
\hline Capital access ability & 0.165 & 0.067 & 0.112 & 4.323 & 0.000 & 0.596 & 1.676 \\
\hline Social relationship & 0.234 & 0.022 & 0.345 & 0.677 & 0.352 & 0.881 & 1.134 \\
\hline Technological activity & 0.043 & 0.058 & 0.021 & 0.343 & 0.121 & 0.910 & 1.098 \\
\hline
\end{tabular}

Table 2 depicts the results of testing manager's ability, wage minimum policy, and firm size on firm performance in the case of Vietnam's real estate and construction sector. In addition, in this study, we also study another five factors such as enterprise and labor characteristics, technological activity, capital access ability, and social relationship. Table 2 also depicts the results according to (1), unstandardized regression coefficient, or (2) standardized regression coefficient. In the theoretical framework, unstandardized coefficients are good for interpretation in connection with raw data, and concluding directly in calculations and analysis. In contrast, standardized coefficients or beta coefficients or weights are obtained from a regression in which the underlying data have been standardized. In this case, the variances of dependent and independent variables are close to 1.

The results of multiple linear regression analysis in Table 2 show that the VIF coefficient was very small, and less than 2 , showing that these independent variables did not have a multicollinearity, in which, multicollinearity refers to a situation when two or more dependent variables in a multiple regression model are highly linearly correlated. In addition, the coefficients of the model are between 0.021 and 0.345 . There are four factors such as manager's ability, firm size, firm characteristics, and capital access ability can affect the profitability of businesses in the case of Vietnam. Three factors such as wage minimum policy, labor characteristics, and technological activity do not affect the profitability of businesses.

Regarding manager's ability, the regression coefficient is 0.134 , significant and positive. It means that a greater ability of managers in the real estate and construction sector will increase the profitability of businesses. In fact, working capital is the lifeblood of not only business, also in the real estate and construction sector. A good manager who can manage the balance between their current assets and their current liabilities. A firm with higher levels of working capital needs more requirements, iron discipline and more ability of their managerial capabilities. This finding is supported by Salehi et al. (2019). In a study in Iran, Salehi et al. (2019) aim to estimate the relationship between management ability and firm performance by using companies listed on the Tehran Stock Exchange. Sample data of 124 companies during 2010-2016 period in which the performance of firms is measured by return on assets, Salehi et al. (2019) conclude that two management factors as management capability and overconfidence are positively correlated with firm efficiency while agency costs have not any impact on firm performance.

In addition, the regression coefficient of firm size is 0.256 , significant and positive. It indicates that the larger firms can reach higher firm efficiency compared with smaller ones. This evidence can be explained by the suggestion of Fernández et al. (2019) who confirm that the performances of large, medium-sized or small businesses are mostly explained by either firm effect or industry effect. In addition, a larger firm can have more opportunities to explore the international market than other ones, Wagner (2019) also indicates that firms with engaging in the international market become larger and more productive than firms with engaging in the local market.

About wage minimum policy and its impact on firm efficiency, in this study, we do not find any evidence in this relationship. It means that changes in wage minimum policy do not affect firm efficiency in the case of real estate and construction firms. This finding can be explained that the real estate and construction sector is not reliant on wage minimum policy. In fact, Vietnam's Salary Report based on recruitment news, real estate or construction is one of the top three highest-paying occupations with an average salary of two to four times the regional base salary and much higher than minimum wages. In addition, the growth of the real estate and construction industry also attracts high wage competition, and more talent candidates to work in this sector so that 
this industry is not affected by the minimum wage policy. In contrast, this finding is not consistent with another study in Indonesia. $\mathrm{Ni}$ and Kurita (2020) conclude that a higher level of minimum wage is consistent with a lower level of employment and productivity of firms.

\section{Conclusions}

It can be said that the real estate and construction industry always plays a particularly important role in each economy. It is the decisive factor for the size and development level of the economy. Besides, it also plays the role of an effective economic regulation. The aim of this research is to estimate the impact of manager's ability, wage minimum policy, and firm size on firm performance. Using 220 real estate and construction firms, results indicate that a greater ability of managers in the real estate and construction sector will increase the profitability of businesses. Similarly, a larger firm can reach a higher firm efficiency compared with a smaller one or a larger firm is more productive than a smaller firm in the case of Vietnam. Further, the efficiency of the real estate and construction firms is not impacted by the changes of wage minimum policy.

In order to improve the firm performance of the real estate and construction firms in Vietnam, the study will propose the following solutions. Firstly, the real estate and construction firms need to expand more production and business in order to explore more profit in the case of Vietnam. Enterprises should enhance manager's ability through increase in training and knowledge change among managers in the business community. Secondly, entrepreneurship is a topic that receives a lot of attention in Vietnam, especially in the context of the country's strong integration with the world economy. In addition, start-up is expected to create economic growth, contribute positively to socio-economic development, contribute to meet the increasing and diverse needs of the society and be an opportunity to develop large enterprises, taking advantage of leading enterprises and large enterprises to develop the country's economy. Thirdly, wage minimum policy is a particularly important part, closely related to other policies in the socio-economic policy system, directly related to economic development, especially other welfare regimes in order to ensure the construction industry development in a better pace, to ensure sustainable development in the future.

\section{References}

Burrus, R.T., Graham, J.E., \& Jones, A.T. (2018). Regional innovation and firm performance. Journal of Business Research, 88, 357-362. https://doi.org/10.1016/j.jbusres.2017.12.042

Department of Statistics of Hanoi, Vietnam.

Fernández, E., Iglesias-Antelo, S., López-López, V., Rodríguez-Rey, M., \& Fernandez-Jardon, C. M. (2019). Firm and industry effects on small, medium-sized and large firms' performance. BRQ Business Research Quarterly, 22(1), 25-35.

Giannetti, C. (2019). Debt specialization and performance of European firms. Journal of Empirical Finance, 53, $257-271$. https://doi.org/10.1016/j.jempfin.2019.07.008

Huang, S.G.H., \& Song, F. M. (2002). The determinants of capital structure: Evidence from China (July 2002). HIEBS (Hong Kong Institute of Economics and Business Strategy) Working Paper, Available at SSRN: https://ssrn.com/abstract=320088 or http://dx.doi.org/10.2139/ssrn.320088

Hussain, S., Quddus, A., Tien, P.T., Rafiq, M., Pavelková, D. (2020). The moderating role of firm size and interest rate in capital structure of the firms: selected sample from sugar sector of Pakistan. Investment Management and Financial Innovations, 17(4), 341-355. doi: http://dx.doi.org/10.21511/imfi.17(4).2020.29

Jensen, M.C. (1986). Agency costs of free cash flow, corporate finance and takeovers. The American Economic Review, 76(2), 323-329.

Jensen, M.C., \& Meckling, W.H. (1976). Theory of the Firm: Managerial Behavior, Agency Costs, and Capital Structure. Journal of Financial Economics, 3(4), 305-360.

Kalkan, A., Erdil, O., \& Çetinkaya, O. (2011). The relationships between firm size, prospector strategy, architecture of information technology and firm performance. Procedia - Social and Behavioral Sciences, 24, 854-869. https://doi.org/10.1016/j.sbspro.2011.09.114

Huynh, T.B. (2020). Several factors affecting the corporate capital structure of the food and beverage industry listed on the Ho Chi Minh City Stock Exchange (HSX). Industry and Trade Magazine. Retrieved from http:/tapchicongthuong.vn/baiviet/mot-so-nhan-to-tac-dong-den-cau-truc-von-doanh-nghiep-nganh-thuc-pham-va-do-uong-niem-yet-tren-so-giao-dichchung-khoan-thanh-pho-ho-chi-minh-hsx-70693.htm

Le, T.T.H., Dao, L.K.O., \& Nguyen, X.D. (2020). An Analysis of Lasso and Ridge Methods of the Relationship between Financial Development and Economic Growth. Journal of Advanced Research in Dynamical and Control Systems, 12(7), 139-146. DOI: $10.5373 / J A R D C S / V 12 I 7 / 20201994$

Le, T.T. (2013). Study on factors affecting business performance of listed food producing and processing companies on Vietnam stock market. Retrieved from http://tailieuso.udn.vn/bitstream/TTHL 125/5284/2/Tomtat.pdf

Sinha, S., Mukherjee, S. (2020). Sales strategies of banks: An empirical study of select private sector banks in India. Journal of Critical Reviews, 7(2), 62-66 
Mukherjee, S., Bhattacharjee, S., \& Singha, S.S. (2017). Workplace spirituality: Perception of employees in selected B-Schools at Kolkata. Purushartha, 10(1), 70-78.

Myers, S. C. (2001). Capital Structure. The Journal of Economic Perspectives, 15(2), 81-102.

Narayan, P.K., Liu, G., Ibrahim, M. (2020). Ethical investing and capital structure. Emerging Markets Review. Available online 3 November 2020, 100774 In Press, Journal Pre-proof. https://doi.org/10.1016/j.ememar.2020.100774

Nguyen, V.D., \& Pham, V.H. (2017). Impacts of factors on production and business of small and medium-sized enterprises in Hai Duong province. Retrieved from http://www1.vnua.edu.vn/tapchi/Upload/2-2017/15.pdf

Nguyen, M.T., Tang, T.N., Lam, H.B. (2020). Factors affecting the business performance of construction enterprises in Bac Lieu province. Industry and Trade Magazine. Retrieved from https://tapchicongthuong.vn/bai-viet/cac-yeu-to-anh-huong-den-hieuqua-hoat-dong-kinh-doanh-cua-doanh-nghiep-xay-dung-tai-tinh-bac-lieu-69683.htm

Nguyen, M.T. (2021). The effect of internal control on the performance of pharmaceutical firms in Vietnam. Accounting, 7(2), 395-400.

Ni, B., \& Kurita, K. (2020). The minimum wage, exports, and firm performance: Evidence from Indonesia. Journal of Asian Economics, 69, 101218. https://doi.org/10.1016/j.asieco.2020.101218

Sadiq, M., Mohamad, S., \& Kwong, W. C. G. (2019). Do CEO Incentives Mediate the Relationship between Political Influences and Financial Reporting Quality?. International Journal of Asian Social Science, 9(3), 276-284.

Sadiq, M., Singh, J., Raza, M., \& Mohamad, S. (2020). The Impact of Environmental, Social and Governance Index on Firm Value: Evidence from Malaysia. International Journal of Energy Economics and Policy, 10(5), 555-562.

Salehi, M., \& Moghadam, S.M. (2019). The relationship between management characteristics and firm performance. Competitiveness Review, 29(4), 440-461. https://doi.org/10.1108/CR-11-2018-0070

Vanacker, T., Zahra, S.A., Holmes, R.M.. (2020). Corporate entrepreneurship, country institutions and firm financial performance. Journal of World Business, November 2020, 101162. In Press, https://doi.org/10.1016/j.jwb.2020.101162

Wagner, J. (2014). Effect of international activity on firm performance. (Uluslararası faaliyetlerin firma performansina etkisi), IZA World of Labor, Say1: 47, 1-10.

Zandi, G., Sadiq, M., \& Mohamad, S. (2019). Big-four auditors and financial reporting quality: evidence from Pakistan. Humanities \& Social Sciences Reviews, 7(2), 369-375.

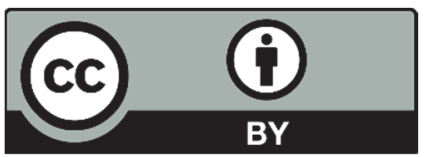

(C) 2021 by the authors; licensee Growing Science, Canada. This is an open access article distributed under the terms and conditions of the Creative Commons Attribution (CC-BY) license (http://creativecommons.org/licenses/by/4.0/). 